\title{
Glycemic Control and Its Determinants among Patients with type 2 Diabetes Mellitus Attending a Teaching Hospital
}

\section{Al-Akour Nemeh ${ }^{1 *}$, Khader Yousef $\mathbf{S}^{2}$ and Alaoui Aysha $\mathbf{M}^{3}$}

${ }^{1}$ Doctor of Nursing Science, Associate Professor in Maternal-Child Health Nursing, School of Nursing, Jordan University of Science and Technology (JUST), P.O. Box (3030) Irbid 22110 Jordan

${ }^{2}$ Department of Community Medicine, Public Health and Family Medicine, Faculty of Medicine, Jordan University of Science and Technology (JUST), P.O. Box (3030) Irbid 22110 Jordan

${ }^{3}$ Master in Public Health (MPH), King Abdullah University Hospital, Jordan

\section{Introduction}

Diabetes mellitus is a group of metabolic diseases characterized by hyperglycemia that result from defects in insulin secretion, or action, or both [1]. The prevalence of type 2 diabetes mellitus is rapidly increasing all over the world [2]. The number of people with diabetes is increasing due to population growth, aging, urbanization, and increasing prevalence of obesity and physical inactivity [2]. In the Arab region, the prevalence of type 2 diabetes mellitus in adult populations was reported as $23.7 \%$ in the Kingdom of Saudi Arabia, 20.1\% in the United Arab Emirates, $20.1 \%$ in Bahrain and 14.9\%, in Kuwait [3,4]. In Jordan, the incidence of type 2 diabetes mellitus is increasing with an overall prevalence of $17.1 \%$ [5]. Glycosylated hemoglobin (HbA1c) as a marker for average blood glucose levels over the previous months prior to the measurement is an important predictor of diabetes complications $[5,6]$. The role of improved glycemic control in reduction microvascular and neurological complications of diabetes was demonstrated in many observational and randomized controlled clinical trials [6-9].

Although glycemic control and its determinants among patients with type 2 diabetes mellitus in Jordan had been investigated in previous studies $[10,11]$ none of these studies was conducted among patients treated in hospitals. The factors associated with glycemic control in hospital patients may be different from those that would be found in primary care level settings or specialized diabetes centers. Patterns of disease burden, disease complexity, comorbidity, disease outcomes, experiences of health care providers and resource utilization have been shown to differ between primary care settings and hospitals $[12,13]$. Recognizing the determinants of poor glycemic may contribute to a clearer understanding of modifiable antecedents of diabetes-related complications and may help to achieve improved glycemic control and improve patient function and outcomes. Therefore, this study was conducted to determine the rate of poor glycemic control and its associated factors among patients attending a tertiary teaching hospital in the north of Jordan.

\section{Subjects and Methods}

\section{Study design and patients}

A cross-sectional design was conducted among patients with type 2 diabetes mellitus aged 18 years and above, who attended diabetes outpatient clinics at the King Abdullah University Hospital (KAUH) in the north of Jordan in the period between June, 2008 and December, 2008. KAUH is a teaching hospital that provides secondary and tertiary health care services to more than 1 million inhabitants in the north of Jordan. A systematic random sample of 533 patients was selected during the study period. Every third patient attended the clinic in each working day was invited to participate in the study. Only patients taking a combination of oral hypoglycemic agents and insulin were included in this study. All invited patients agreed to participate in this study.

\section{Instruments}

Six questionnaires were used to collect the necessary information about factors that might affect the glycemic control. The first questionnaire sought information about socio-demographic and relevant characteristics including age, gender, and onset and duration of type 2 diabetes mellitus. Information related to patient's self-care behaviors and other variables that may influence an individual's ability and willingness to provide diabetes self-care were collected using different questionnaires including: Diabetes Knowledge Test questionnaire [14], Attitude Toward Diabetes Scale (Positive Attitude Scale and Negative Attitude Scale) [15], Family and Friends' Support Scale [15], Long-Term Care Benefits Scale [15], and Self-Care Adherence Scale of the Diabetes Care Profile (DCP) [15]. In this study a symmetrical back-translation method was used to translate all study questionnaires. Higher scores on the Diabetes Knowledge Test questionnaire indicate higher levels of patient's knowledge about diabetes and its care. A higher score on the Positive Attitude Scale indicate that the patient would have positive coping in dealing with type 2 diabetes mellitus on a daily basis. High scores on the Negative Attitude Scale indicate perception of more maladaptation of the patient toward the diabetes and its treatment. Higher scores on the Family and Friends' Support Scale indicate the patients' perception of more family and friends' support about diabetes and its management. A higher score on the Long- Term Care Benefits Scale indicates that the patient's health beliefs were directed toward a positive outlook on recommended health regimens of type 2 diabetes mellitus in preventing or delay. A higher score of Self - Care Adherence Scale indicates the patients were compliant with recommended health regimens most of the time (see the appendix for some of the questions on the questionnaires).

\section{Laboratory and anthropometric measurements}

The last readings of $\mathrm{HbA} 1 \mathrm{c}$ were abstracted from patient's records. All abstracted last readings were measured 1 to 5 months before the date of data abstraction. In the laboratory, $\mathrm{HbAlc}$ was analyzed by suitable tubes (EDTA tubes) on Hitachi 917 analyzer (Roche] which is based on the turbidimetric inhibition immunoassay (TINIA) for hemolyzed

*Corresponding author: Nemeh Al-Akour, Doctor of Nursing Science, Associate Professor in Maternal-Child Health Nursing, School of Nursing, Jordan University of Science and Technology, Irbid, Jordan, P.O. Box 3030, Jordan, E-mail:alakour@ just.edu.jo

Received March 14, 2011; Accepted May 13, 2011; Published May 16, 2011

Citation: Al-Akour NA, Khader YS, Alaoui AM (2011) Glycemic Control and Its Determinants among Patients with type 2 Diabetes Mellitus Attending a Teaching Hospital. J Diabetes Metab 2:129. doi:10.4172/2155-6156.1000129

Copyright: (c) 2011 Al-Akour NA, et al. This is an open-access article distributed under the terms of the Creative Commons Attribution License, which permits unrestricted use, distribution, and reproduction in any medium, provided the original author and source are credited. 
Citation: Al-Akour NA, Khader YS, Alaoui AM (2011) Glycemic Control and Its Determinants among Patients with type 2 Diabetes Mellitus Attending a Teaching Hospital. J Diabetes Metab 2:129. doi:10.4172/2155-6156.1000129

Page 2 of 5

whole blood. Glycemic status was categorized as good glycemic control if $\mathrm{HbA} 1 \mathrm{c}<7 \%$ and poor glycemic control if HbAlc $\geq 7 \%$ [6,7]. Weight and height were measured with light clothes and taking the shoes off. Weight was taken to the nearest 0.5 kilogram and height was taken to the nearest centimeter. Body mass index (BMI) was calculated as the ratio of weight in kilograms to the square of height in meters.

\section{Statistical analyses}

Data were entered into computer using the Statistical Package for Social Sciences software, SPSS (SPSS Inc., Chicago, IL, USA) version 15. Data were described using means, standard deviation and proportions wherever appropriate. Differences in rate of poor glycemic control according to clinical and categorical variables were analyzed using chisquare test. Differences in means between controlled (HBA1C $<7 \%$ ) and not controlled (HBA1C $\geq 7 \%$ ) were analyzed using t-test. Multiple binary logistic regressions were used to determine factors associated with poor glycemic control". Backward stepwise elimination method

\begin{tabular}{|c|c|c|}
\hline Variable & $\mathbf{n}$ & (\%) \\
\hline $\begin{array}{l}\text { Sex } \\
\text { Male } \\
\text { Female }\end{array}$ & $\begin{array}{l}203 \\
330\end{array}$ & $\begin{array}{l}(38.1) \\
(61.9)\end{array}$ \\
\hline $\begin{array}{l}\text { Age } \\
<40 \\
40-49 \\
50-59 \\
\geq 60\end{array}$ & $\begin{array}{l}118 \\
140 \\
134 \\
141\end{array}$ & $\begin{array}{l}(22.1) \\
(26.3) \\
(25.1) \\
(26.5)\end{array}$ \\
\hline $\begin{array}{l}\text { Martial Status } \\
\text { Married } \\
\text { Not Married }\end{array}$ & $\begin{array}{l}409 \\
124\end{array}$ & $\begin{array}{l}(76.7) \\
(23.3)\end{array}$ \\
\hline $\begin{array}{l}\text { Family size } \\
\leq 5 \\
>5\end{array}$ & $\begin{array}{l}236 \\
297\end{array}$ & $\begin{array}{l}(44.3) \\
(55.7)\end{array}$ \\
\hline $\begin{array}{l}\text { Education } \\
\leq 6 \\
7-12 \\
>12\end{array}$ & $\begin{array}{c}245 \\
196 \\
92\end{array}$ & $\begin{array}{l}(46.0) \\
(36.8) \\
(17.3)\end{array}$ \\
\hline $\begin{array}{l}\text { Employment Status } \\
\text { Employed } \\
\text { Not Employed }\end{array}$ & $\begin{array}{l}216 \\
317\end{array}$ & $\begin{array}{l}(40.5) \\
(59.5)\end{array}$ \\
\hline $\begin{array}{l}\text { Smoking } \\
\text { Yes } \\
\text { No }\end{array}$ & $\begin{array}{l}128 \\
405\end{array}$ & $\begin{array}{l}(24.0) \\
(76.0)\end{array}$ \\
\hline $\begin{array}{l}\text { Body Mass Index } \\
\text { Normal } \\
\text { Overweight } \\
\text { Obesity }\end{array}$ & $\begin{array}{l}97 \\
317 \\
119\end{array}$ & $\begin{array}{l}(18.2) \\
(54.5) \\
(22.3)\end{array}$ \\
\hline $\begin{array}{l}\text { Family History } \\
\text { Yes } \\
\text { No }\end{array}$ & $\begin{array}{l}477 \\
56\end{array}$ & $\begin{array}{l}(89.5) \\
(10.5)\end{array}$ \\
\hline $\begin{array}{l}\text { Duration } \\
\leq 10 \\
>10\end{array}$ & $\begin{array}{l}256 \\
277\end{array}$ & $\begin{array}{l}(48.0) \\
(52.0)\end{array}$ \\
\hline $\begin{array}{l}\text { HBA1c } \\
<7 \% \\
\geq 7 \%\end{array}$ & $\begin{array}{l}258 \\
275\end{array}$ & $\begin{array}{l}(48.4) \\
(51.6)\end{array}$ \\
\hline $\begin{array}{l}\text { Visit to doctors } \\
\text { Every month } \\
\text { Every two months }\end{array}$ & $\begin{array}{l}203 \\
330\end{array}$ & $\begin{array}{l}(38.1) \\
(61.9)\end{array}$ \\
\hline $\begin{array}{l}\text { Heart disease } \\
\text { No } \\
\text { Yes }\end{array}$ & $\begin{array}{l}313 \\
220\end{array}$ & $\begin{array}{l}(58.7) \\
(41.3)\end{array}$ \\
\hline $\begin{array}{l}\text { Renal Disease } \\
\text { No } \\
\text { Yes }\end{array}$ & $\begin{array}{c}487 \\
46\end{array}$ & $\begin{array}{l}(91.4) \\
(08.6)\end{array}$ \\
\hline
\end{tabular}

Table 1: The socio-demographic, clinical, and relevant characteristics of 533 patients with type 2 diabetes mellitus who attended a teaching hospital in the north of Jordan.

\begin{tabular}{|c|c|c|c|c|c|}
\hline \multirow{2}{*}{ Variable } & \multicolumn{2}{|c|}{ HBA1c $<7$} & \multicolumn{2}{|c|}{ HBA1c $\geq 7$} & \multirow{2}{*}{ P-value } \\
\hline & n & $(\%)$ & n & $(\%)$ & \\
\hline $\begin{array}{l}\text { Sex } \\
\text { Male } \\
\text { Female }\end{array}$ & $\begin{array}{l}90 \\
168\end{array}$ & $\begin{array}{l}(44.3) \\
(50.9)\end{array}$ & $\begin{array}{l}113 \\
102\end{array}$ & $\begin{array}{l}(55.7) \\
(49.1)\end{array}$ & 0.140 \\
\hline $\begin{array}{l}\text { Age } \\
<40 \\
40-49 \\
50-59 \\
60+\end{array}$ & $\begin{array}{l}60 \\
65 \\
63 \\
70\end{array}$ & $\begin{array}{l}(50.8) \\
(46.4) \\
(47.0) \\
(49.6)\end{array}$ & $\begin{array}{l}58 \\
75 \\
71 \\
71\end{array}$ & $\begin{array}{l}(49.2) \\
(53.6) \\
(53.0) \\
(50.4)\end{array}$ & 0.875 \\
\hline $\begin{array}{l}\text { Martial Status } \\
\text { Married } \\
\text { Not Married } \\
\end{array}$ & $\begin{array}{l}193 \\
65\end{array}$ & $\begin{array}{l}(47.2) \\
(52.4)\end{array}$ & $\begin{array}{l}216 \\
59\end{array}$ & $\begin{array}{l}(52.8) \\
(47.6)\end{array}$ & 0.307 \\
\hline $\begin{array}{l}\text { Family size } \\
\leq 5 \\
>5\end{array}$ & $\begin{array}{l}112 \\
146\end{array}$ & $\begin{array}{l}(47.5) \\
(49.2)\end{array}$ & $\begin{array}{l}124 \\
151\end{array}$ & $\begin{array}{l}(52.5) \\
(50.8)\end{array}$ & 0.696 \\
\hline $\begin{array}{l}\text { Education } \\
\leq 6 \\
7-12 \\
>12\end{array}$ & $\begin{array}{l}123 \\
93 \\
42\end{array}$ & $\begin{array}{l}(50.2) \\
(47.4) \\
(45.7)\end{array}$ & $\begin{array}{l}122 \\
103 \\
50\end{array}$ & $\begin{array}{l}(49.8) \\
(52.6) \\
(54.3)\end{array}$ & 0.716 \\
\hline $\begin{array}{l}\text { Employment Status } \\
\text { Employed } \\
\text { Not Employed }\end{array}$ & $\begin{array}{l}101 \\
157\end{array}$ & $\begin{array}{l}(46.8) \\
(49.5)\end{array}$ & $\begin{array}{l}115 \\
160\end{array}$ & $\begin{array}{l}(53.2) \\
(50.5)\end{array}$ & 0.530 \\
\hline $\begin{array}{l}\text { Smoking } \\
\text { Yes } \\
\text { No }\end{array}$ & $\begin{array}{l}202 \\
56\end{array}$ & $\begin{array}{l}(49.9) \\
(43.8)\end{array}$ & $\begin{array}{l}203 \\
72\end{array}$ & $\begin{array}{l}(50.1) \\
(56.3)\end{array}$ & 0.227 \\
\hline $\begin{array}{l}\text { Body Mass Index } \\
\text { Normal } \\
\text { Overweight } \\
\text { Obesity }\end{array}$ & $\begin{array}{l}46 \\
157 \\
55\end{array}$ & $\begin{array}{l}(47.4) \\
(49.5) \\
(46.2)\end{array}$ & $\begin{array}{l}51 \\
160 \\
64\end{array}$ & $\begin{array}{l}(52.6) \\
(50.5) \\
(53.8)\end{array}$ & 0.809 \\
\hline $\begin{array}{l}\text { Family History } \\
\text { Yes } \\
\text { No }\end{array}$ & $\begin{array}{l}232 \\
26\end{array}$ & $\begin{array}{l}(48.6) \\
(46.4)\end{array}$ & $\begin{array}{l}245 \\
30\end{array}$ & $\begin{array}{l}(51.4) \\
(53.6)\end{array}$ & 0.754 \\
\hline $\begin{array}{l}\text { Duration } \\
\leq 10 \\
>10\end{array}$ & $\begin{array}{l}137 \\
121\end{array}$ & $\begin{array}{l}(53.5) \\
(43.7)\end{array}$ & $\begin{array}{l}119 \\
156\end{array}$ & $\begin{array}{l}(46.5) \\
(56.3)\end{array}$ & 0.023 \\
\hline $\begin{array}{l}\text { Visit to doctor } \\
\text { Every month } \\
\text { Every two months }\end{array}$ & $\begin{array}{l}94 \\
164\end{array}$ & $\begin{array}{l}(46.3) \\
(49.2)\end{array}$ & $\begin{array}{l}109 \\
166\end{array}$ & $\begin{array}{l}(53.7) \\
(50.3)\end{array}$ & 0.447 \\
\hline $\begin{array}{l}\text { Heart disease } \\
\text { No } \\
\text { Yes }\end{array}$ & $\begin{array}{l}147 \\
111\end{array}$ & $\begin{array}{l}(47.0) \\
(50.5)\end{array}$ & $\begin{array}{l}166 \\
109\end{array}$ & $\begin{array}{l}(53.0) \\
(49.5)\end{array}$ & 0.427 \\
\hline $\begin{array}{l}\text { Renal Disease } \\
\text { No } \\
\text { Yes }\end{array}$ & $\begin{array}{l}234 \\
24\end{array}$ & $\begin{array}{l}(48.0) \\
(52.2)\end{array}$ & $\begin{array}{l}253 \\
22\end{array}$ & $\begin{array}{l}(52.0) \\
(47.8)\end{array}$ & 0.593 \\
\hline
\end{tabular}

Table 2: The rate of poor glycemic control according to socio-demographic, clinical, and relevant characteristic of patients.

was used to reach the "best fitting model" that includes the significant variables only. A P-value of $<0.05$ was considered statistically significant.

\section{Results}

\section{Patients' characteristics}

This study included a total of 533 (203 males and 330 females) patients with type 2 diabetes mellitus. Their age ranged from 18 to 79 years with a mean (SD) of 50.1 (14.1). The BMI values ranged from 18.9 to $41.2 \mathrm{~kg} / \mathrm{m}^{2}$ with a mean (SD) of $27.6(3.5) \mathrm{kg} / \mathrm{m}^{2}$. More than half of participants (59.5\%) were unemployed and $17.3 \%$ had more than 12 years of education. The majority of participants (89.5\%) had a family history of diabetes and $52.0 \%$ had diabetes for duration of more than 10 years. The participants' socio-demographic, clinical, and relevant characteristics are shown in Table 1.

\section{The rate of poor glycemic control}

Of the total 533 patients with type 2 diabetes, $51.6 \%$ had poor glycemic control. Table 2 shows the rate of poor glycemic control according to socio-demographic, clinical, and relevant characteristic of 
participants. The rate of poor glycemic control among patients having diabetes for more than 10 years $(56.3 \%)$ was significantly higher than that among those having diabetes for 10 years or less $(46.5 \%)$. The rate of poor glycemic control did not differ significantly among patients according to their other characteristics.

\section{Glycemic control and diabetes related variables}

Table 3 presents the differences in the mean scores of knowledge of diabetes scale, attitude toward diabetes scale, perceived family and friends support scale, benefits of treatment scale, and adherence with health regimens scale between patients according to their glycemic control. Patients with poor glycemic control did not differ significantly in their knowledge of diabetes, attitude toward diabetes, perceived family and friend support, long term benefit score, and self care adherence score.

\section{Multivariate analysis of factors associated with poor glycemic control}

In the multivariate analysis (Table 4), the only variables that were significantly associated with poor glycemic control were duration of diabetes and family support score. Patients with duration of diabetes of more than 10 years had higher odds of poor glycemic control $(\mathrm{OR}=1.53$; 95\% CI: 1.09, 2.17) compared to those with duration of 10 years or less. Increased family and friend support score was associated with decreased odds of poor glycemic control (OR=0.96; 95\% CI: 0.93 , 0.98).

\section{Discussion}

More than half (51.6\%) of participants with type 2 diabetes mellitus had poor glycemic control. This finding is similar to that reported in Saudi Arabia where half of the studied populations had poor glycemic control [16,17]. In Bahrain, $78.2 \%$ of diabetic patients had poor glycemic control [18]. In USA, data from National Health and Nutrition Examination Surveys (1988-1994 and 1999-2002) reported that $42 \%$ and $50 \%$ of people with diabetes respectively met the HbAlc target of $7 \%[19,20]$. In the United Kingdom (UK), a series of retrospective analysis of data found that $79 \%$ and $76 \%$ of patients in 1998 and 2002, respectively had inadequate glycemic control with $\mathrm{HbAlc}>7.5 \%$ [21]. In other studies in Jordan, Khattab et al. [11] reported that $65.1 \%$ of

\begin{tabular}{|c|c|c|c|c|c|}
\hline & \multicolumn{2}{|c|}{ HBA1c $<7$} & \multicolumn{2}{|c|}{ HBA1c $\geq 7$} & \multirow[t]{2}{*}{ P-value } \\
\hline & Mean & SD & Mean & SD & \\
\hline Knowledge of diabetes test & 7.5 & 1.9 & 7.4 & 1.9 & 0.297 \\
\hline Positive attitude toward diabetes & 6.9 & 2.8 & 6.7 & 2.8 & 0.281 \\
\hline Negative attitude toward diabetes & 20.0 & 5.1 & 20.4 & 5.0 & 0.469 \\
\hline Perceived family and friend support & 44.3 & 5.2 & 43.4 & 5.0 & 0.062 \\
\hline Long term benefit & 20.3 & 3.9 & 2.3 & 4.4 & 0.861 \\
\hline Self care adherence & 13.4 & 2.4 & 13.7 & 2.9 & 0.235 \\
\hline
\end{tabular}

Table 3: The difference in the means scores of knowledge of diabetes scale attitude toward diabetes scale, perceived family and friends support scale, benefits of treatment scale, and adherence with health regimens scale between patients according to their glycemic control.

\begin{tabular}{|l|l|l|}
\hline Variable & OR $(\mathbf{9 5 \%}, \mathbf{C I})$ & P-value \\
\hline $\begin{array}{l}\text { Duration of diabetes } \\
\leq 10 \text { years } \\
>10 \text { years }\end{array}$ & 1 & \\
\hline Family and friend support score & $1.53(1.09,2.17)$ & 0.015 \\
\hline
\end{tabular}

Table 4: Multivariate analysis of factors associated with poor glycemic contro among patients with type 2 diabetes mellitus. the diabetic patients attending the National Center for Diabetes, Endocrinology and Genetics (NCDEG) had HbAlc $\geq 7 \%$. While, Al Omari et al. [10] reported that $43.9 \%$ of the patients who attended the diabetic clinic at the primary care level in the university teaching family health centre had $\mathrm{HbAlc} \geq 7 \%$. The lower rate of poor glycemic among patients treated at the primary care level may be explained by that primary health care settings treat patients with medical conditions before they become serious enough to require hospitalization or emergency treatment. In the university teaching family health centre, there is close follow up in the clinic and continuity of care is ensured as the patient has to see the physician to take the prescription which prescribed on monthly basis. Besides the proper counseling and teaching of diabetic patients in the clinic there is regular group counseling with the presence of family physicians, nurses, pharmacist and dietitian. This approach had been shown to enhance the patient-doctor relationship and to have a positive effect on the compliance of the patient. On the other hand, the majority of patients treated in NCDEG are referred form hospital and medical centers to receive the specialized diabetes care. Being a referral specialized canter might explain the higher rate of poor glyemic control compared to that in other setting in Jordan.

Previous studies had found conflicting results on factors associated with poor glycemic control. This may be explained by the differences in study designs, characteristics of the study populations, and the types of treatment facilities. Furthermore, this may be explained by differences in race and ethnicity of the studied populations. Dosage for oral medication or insulin, compliance with regimens, self-monitoring of blood glucose, and socio-economic status may differ by race/ethnic group leading to greater improvements in control in some groups but not in others. Socio-economic status may influence diabetes management and control since it is often associated with access to health care, healthcare utilization, use of medication, and access to good nutrition.

The current study showed that patients with duration of diabetes of more than 10 years were more likely to have poor glycemic control compared to those with duration of 10 years or less. This finding is consistent with that reported in previous studies where longer duration of diagnosed diabetes was associated with increased $\mathrm{HbAlc}$ values [22-24]. This might be explained by that the amount of carbohydrate attached to the HbAlc increases with increasing duration of the disease [25]. The United Kingdom Prospective Diabetes Study (UKPDS) [26] and the Belfast Diet Study [27] showed that beta cell function decreased during the 5 to 10 years after diagnosis of diabetes which lead to decreases in insulin.

Increased family and friend support score was shown in this study to be associated with decreased odds of poor glycemic control. This finding is in agreement with the findings of others. Delamater et al. [28] have shown that low levels of conflict, high levels of cohesion and organization, and good communication patterns are associated with better regimen adherence. Furthermore, McDonald et al. [29] found that social support may enhance diabetes mellitus management and Gilliland et al. [30] reported that those exposed to treatment entailing social support maintain steady HbA1c level. Thompson et al. [31] and Harris [32] found that greater level of social support from spouses and other family members are associated with better adherence with health regimen. Winkler et al. [33] found social support also serves to buffer the adverse effect of stress on diabetes management. On the other hand, Chlebowy et al. [34] found that social support was not significantly associated with glycemic control among Caucasians and African Americans. 
In the present study, knowledge, attitude, and self-care adherence were not found to have significant relationships with glycemic control. The finding is similar to the findings of other authors who found that there was no correlation between knowledge [35] and attitude [36] with glycemic control. However, other studies [37-39] found that diabetes knowledge, attitude and adherence to health regimens were associated with glycemic control. Lack of relationships among age and gender and poor glycemic control in our study is consistent with Shani et al. [40] who found neither age nor gender were related to the achievement of good glycemic control. Moreira et al. [41] found that gender was not associated with improved glycemic control. However, Wahba and Chang [42] found that older patients had better improvements in $\mathrm{HbA1c}$.

In conclusion, the proportion of poor glycemic control among patients with type 2 diabetes mellitus in KAUH is relatively high. Duration of diabetes of more than 10 years and decreased family support score were associated with poor glycemic control. Educational programs that emphasize lifestyle modification with emphasis on family support are encouraged.

\section{References}

1. Florence JA, Yeager BF (1999) Treatment of Type 2 diabetes mellitus. Am Fam Physician 59: 2835-2844, 2849-2850.

2. King H, Aubert R, Herman W (1998) Global burden of diabetes, 1995-2025: prevalence, numerical estimates, and projections. Diabetes Care 21: 14141431.

3. Al-Nozha MM, Al-Maatouq MA, Al-Mazrou YY, Al-Harthi SS, Arafah MR, et al (2004) Diabetes mellitus in Saudi Arabia. Saudi Med J 25: 1603-1610.

4. Diabetes Atlas second edition, International Diabetes Federation (2003).

5. Ajlouni K, Khader Y, Batieha A, Ajlouni H, El-Khateeb M (2008) An increase in prevalence of diabetes mellitus in Jordan over 10 years. J Diabetes Complications 22: 317-324

6. The effect of intensive treatment of diabetes on the development and progression of long-term complications in insulin-dependent diabetes mellitus. The Diabetes Control and complications Trial Research Group (1993) N Engl J Med 329: 977-986.

7. Intensive blood-glucose control with sulphonylureas or insulin compared with conventional treatment and risk of complications in patients with type 2 diabetes (UKPDS 33). UK Prospective Diabetes Study (UKPDS) Group. (1998) Lancet 352: 837-853.

8. Effect of intensive blood-glucose control with metformin on complications in overweight patients with type 2 diabetes (UKPDS 34). UK Prospective Diabetes Study (UKPDS) Group. (1998) Lancet 352: 854 -865.

9. Stettler C, Allemann S, Jüni P, Cull CA, Holman RR, Egger M, et al. (2006) Glycemic control and macrovascular disease in types 1 and 2 diabetes mellitus: Meta-analysis of randomized trials. Am Heart J 152: 27-38.

10. Al Omari M, Khader Y, Dauod AS, Al-Akour N, Khassawneha AH, Al-Ashkera E, et al. (2009) Glycaemic control among patients with type 2 diabetes mellitus treated in primary care setting in Jordan. Prim Care Diabetes 3:173-179.

11. Khattab M, Khader Y, Al-Khawaldeh A, Ajlouni K (2010) Factors associated with poor glycaemic control among patients with Type 2 diabetes. J Diabetes Complications 24: 84-89.

12. Chin MH, Zhang JX, Merrell K (2000) Specialty differences in the care of older patients with diabetes. Med Care 38: 131-140.

13. Mooradian AD (2003) Cardiovascular disease in type 2 diabetes Mellitus: current management guidelines. Arch Intern Med 163: 33-40.

14. Fitzgerald JT, Funnell MM, Hess GE, Barr B S, Anderson RM, et al. (1998) The reliability and validity of a brief Diabetes Knowledge test. Diabetes Care 21: $706-710$

15. Fitzgerald JT, Davis WK, Connell CM, Hess GE, Funnell MM, et al. (1996) Development and validation of the diabetes Care Profile. Eval Health Prof 19: 208-230.
16. Al-Nuaim AR, Mirdad S, Al-Rubeaan K, Al-Mazrou Y, Al-Attas O, et al. (1998) Pattern and factors associated with glycemic control of saudi diabetic patients. Ann Saudi Med 18: 109-112.

17. Abdel-Gayoum A, Musa AS (2009) The effect of glycemic control on serum lipids and calcium - phosphate profiles in patients With type 2 diabetes mellitus. The Egyptian Journal of Biochemistry \& Molecular Biology 27: 79-92.

18. Modebe O, Masoomi MA (2000) Microalbuminuria and associated factors in Bahraini patients with type 2 diabetes mellitus. Ann Saudi Med 20: 157-160.

19. Resnick HE, Foster GL, Bardsley J, Ratner RE (2006) Achievements of American Diabetes Association Clinical practice Recommendations among U.S. Adults with Diabetes, 1999-2002 The National Health and Nutrition Examination survey. Diabetes Care 29: 531-537.

20. Saaddine JB, Cadwell B, Gregg EW, Michael M, Engelgau MM, Vinicor F, et al. (2006) Improvements in diabetes processes of care and intermediate outcomes: United states, 1988-2002. Ann Intern Med 14: 465-474.

21. Fox KM, Gerber RA, Bolinder B, Chen J, Kumar S (2006) Prevalence of Inadequate Glycemic Control Among patients with type 2 diabetes in the United Kingdom general practice research data base: A series of retrospective analysis of data from 1998 through 2002. Clin Ther 28: 388-395

22. Verma M, Paneri S, Badi P, Raman G (2006) Effect of increasing duration of diabetes mellitus type 2 on glycated hemoglobin and insulin sensitivity. Indian Journal of Clinical Biochemistry 21: 42-146.

23. Benoit SR, Fleming R, Tsimikas AP, Ming Jl (2005) Predictors of glycemic control among patients with type 2 diabetes: A longitudinal study. BMC Public Health 5: 1-9.

24. Corpus RA, George PB, House JA, Dixon SR, Ajluni SC, et al. (2004) Optimal glycemic control is associated with a lower rate of target vesse revascularization in treated type II diabetic patients undergoing elective percutaneous coronary intervention. J Am Coll cardiol 43: 8-14.

25. Sampson MJ, Hughes DA, Carrier MJ and Davies IR (2002) Status of HbA1c during acute hyperglycemia in type 2 diabetes. Diabetes care 25: 537-541.

26. U.K. prospective diabetes study 16. Overview of 6 years' therapy of type I diabetes: a progressive disease. U.K. Prospective Diabetes Study Group (1995). Diabetes 44: 1249-1258.

27. Levy J, alkinson AB, Bell PM, Mccance Dr, Hadden DR (1998) Beta -cell deterioration determines the onset and rate of progression of secondary dietary failure in type 2 type 2 diabetes mellitus: the 10 year follows up of the Belfast diet study. Diabet Med 15: 290-296.

28. Delamater AM, Jacobson AM, Anderson B, Cox D, Fisher L, et al. (2001) Psychosocial therapies in diabetes: report of the psychosocial therapies working group. Diabetes Care 19: 1286-1292.

29. McDonald PE, Wykle ML, Misra R, Suwonnaroop N, Burant CJ (2002) Predictors of social support, acceptance, health promoting behaviors, and glycemic control in African-Americans with type 2 diabetes. J Natl Black Nurses Assoc 13: 23-30

30. Gilliland S, Azen SP, Perez GE, Carter JS (2002) Strong in body and spirit: lifestyle intervention for Native American adults with diabetes in New Mexico. Diabetes Care 25: 78-83.

31. Thompson SJ, Auslander WF, White NH (2001) Comparison of single-mothe and two -parent families on metabolic control of children with diabetes. Diabetes care 24: 234-238.

32. Harris MI (2001) Frequency of blood glucose monitoring in relation to glycemic control in patients with Type 2 diabetes. Diabetes Care 24: 979-982.

33. Winkler A, Teuscher AU, Mueller B, Diem P (2002) Monitoring adherence to prescribed medication in type 2 diabetic patients treated with sulfonylureas. Swiss Med Wkly 132: 379-385.

34. Chlebowy DO, Garvin BJ (2006) Social support, Self-efficacy, and outcome expectations, Impact on self care behaviors and glycemic control in Caucasian and Africans Americans adults with type 2 diabetes. Diabetes Educ 32: 777 786

35. Carlos SD, Newby KL, Darren MK, Vic H, Mark FN, et al. (2005) Diabetes related knowledge, atherosclerotic risk factor control, and outcomes in acute coronary syndromes. The American journal of cardiology 95: 1290-1294.

36. Brooks RJ, Roxburgh S (1999) Gender differences in the effect of the subjective experience of diabetes and sense of control on distress. Health 3: 399-420. 
Citation: Al-Akour NA, Khader YS, Alaoui AM (2011) Glycemic Control and Its Determinants among Patients with type 2 Diabetes Mellitus Attending a Teaching Hospital. J Diabetes Metab 2:129. doi:10.4172/2155-6156.1000129

Page 5 of 5

37. Bains SS, Egede LE (2011) Associations between health literacy, diabetes knowledge, self-care behaviors, and glycemic control in a low income population with type 2 diabetes. Diabetes Technol Ther 13: 335-341.

38. Rhee MK, Slocum W, Ziemer DC, Culler SD, Cook CB, et al. (2005) Patient adherence improves glycemic control. Diabetes Educ 31: 240-50.

39. Gopichandran V, Mahadevan S, Ravikumar L, Parasuraman G, Sathya A, et al. (2007) Assessment of knowledge, attitudes and practices about tight glycemic control in the critically ill among endocrinologists and intensivists practicing in Chennai. IJCCM 11: 122-126.
40. Shani M, Taylor T, Vinker S, Lustman A, Erez R, et al. (2008) Characteristics of Diabetics with poor Glycemic control who achieve good control. J Am Board Fam Med 21: 490-496.

41. Moreira Jr EDM, Neves RCS, Nunes ZO, de Almeida MCC, Mendes ABV, et al. (2010) Glycemic control and its correlates in patients with diabetes $n$ Venezuela: Results from a nationwide survey. Diabetes Res Clin Pract 87: 407-414.

42. Wahba H, Chang YF (2007) Factors Associated with Glycemic Control in Patients with Type 2 Diabetes Mellitus in Rural Areas of the United States. Insulin 2: 134-141. 